\author{
Sustinere \\ Journal of Environment and Sustainability \\ Volume 4 Number 3 (2020) 205-223 \\ Print ISSN: 2549-1245 Online ISSN: 2549-1253 \\ Website: https://sustinerejes.com E-mail: sustinere.jes@iain-surakarta.ac.id
}

\title{
RESEARCH PAPER \\ Anthropogenic influences on morphological changes in the Progo River, Daerah Istimewa Yogyakarta Province, Indonesia
}

\author{
Akhmad Zamroni1*, Bayurohman Pangacella Putra², Haris Nur Eka Prasetya ${ }^{2}$ \\ ${ }^{1}$ Department of Geological Engineering, Institut Teknologi Nasional Yogyakarta, Indonesia \\ ${ }^{2}$ Department of Mining Engineering, Institut Teknologi Nasional Yogyakarta, Indonesia \\ Article history: \\ Received 12 June 2020 | Accepted 8 November 2020 | Available online 31 December 2020
}

\begin{abstract}
Changes in the river morphology require knowledge of the suite of drivers that control it, whether natural or human. The study aims to analyze the anthropogenic influences on morphological changes in the Progo River using Google Earth Images. It is essential to know the recent changes in the morphology of the Progo River so that stakeholders can make policies to control human activities that influence the morphology changes of the Progo River. The study area is located in Bantul Regency, Daerah Istimewa Yogyakarta Province, Java Island, Indonesia. The size of the Progo River watershed is around 17,432 square kilometers. Google Earth Images analysis is carried out to analyze the morphological changes of the Progo River from 2012 to 2019. The result shows that land-use changes due to dam construction affected the sediment supply downstream of the dam. In addition, land-use changes around the Progo River due to the opening of agricultural land and settlement areas had an effect on decreasing the infiltration area, so that the number of trees holding the soil from erosion was reduced, producing more eroded sediment that flowed to the river. Sand mining in the river could cause the deepening of water depths and a decrease in the average height of the riverbed.
\end{abstract}

Keywords: river; anthropogenic; land-use; human activities; morphological

\section{Introduction}

Some studies about the river morphological changes have been analyzed for several years (e.g., Raven et al., 2010; Lane et al., 2010; Pan et al., 2011; Uddin et al., 2011; Kiss \& Blanka, 2012; Brunier et al., 2014; Zhang et al., 2015; Williams et al., 2015; Du et al., 2016; Jiang et al., 2017). Some of them were due to natural factors, human factors, or both combined. The study of river morphological changes was beneficial in showing that river channels can pass different phases of adjustment, river morphology can change briefly and dramatically, and changes in the river morphology have implications in some damages, for instance, structural damages, flooding, ecological loss, and loss of groundwater resources (Ziliani \& Surian, 2012). The river 
morphology can change over time as a result of hydraulic forces that work both on the riverbank and riverbed. These changes can occur quickly or gradually, and natural factors or human factors can cause them. Every change that occurs at a point in the river section will affect the upstream and downstream conditions. In addition to climate-induced changes, river morphology responds to human activities such as the construction of embankments and bridges, construction of dams, sand mining, diversion of bed material and/or flow, exploitation of water for industrial, agricultural, and urban needs. These activities have physical, environmental, and ecological impacts, for example, streambed mobilization, degradation, scouring, changes in hydrologic regime, and aggradation (Isik et al., 2008).

The challenges in interpreting river morphology changes are a detailed reconstruction of changes, quantitative analysis of controlling factors, and identification of relation of controlling factors and changes in river morphology (Ziliani \& Surian, 2012). Changes in the river morphology require knowledge of the suite of drivers that influence it, whether natural or human. Natural drivers usually occur in the long term due to climate factors, whereas human drivers control land-use changes that directly or indirectly impact water resource management (Downs et al., 2013). However, dramatic changes occur in a relatively short time that can change the river morphology, including volcanic eruptions and the construction of dams and canals. So, observing each river channel's details is needed to link the morphological changes in the river and the factors that control them (Ziliani \& Surian, 2012).

Anthropogenic effects describe the strong human impact on fluid systems associated with river impacts, for example, mining activities, soil conservation, and dam construction. It measures the effects on hydrologic flow, flow morphology, and sediment loading (Isik et al., 2008; Du et al., 2016). Mining activities, especially sand mining along rivers, are the significant impacts of riverbed evolution, including the deepening of the water depth, the lowering of the average riverbed elevation, the flooding of the longitudinal riverbed gradient, and the increasing of the channel capacity. The new sediment load from the upstream will be deposited in the former sand mining area to adjust the riverbed topography. This condition will make the discharge of sediment into the estuary will be reduced. Soil conservation upstream can reduce erosion. Reduced erosion will reduce the average sediment load along the river. However, the study of soil conservation's effect on the quantity of sediment load supply in the river will be difficult to explain if there is a dam, which is also a factor in reducing the amount of sediment load. Dam construction has caused a decrease in the average sediment load supply along the river due to a large amount of sediment trapped behind the dam (Du et al., 2016).

The area of the Progo River watershed is around 17,432 square kilometers. Previous studies of morphological changes in the Progo River after the eruption of Mount Merapi in 2010 have been conducted. Sediment material upstream of the Progo River is a source of sediment downstream. The quantity of sediment from the upstream causes relatively abrupt morphological changes in the Progo River. Morphological changes will affect hydraulic conditions like erosion and sedimentation processes, which then affect the stability of construction in the water (Harsanto, 2015; Fitriadin et al., 2017). This study aims to analyze the anthropogenic influences on morphological changes in the Progo River by using Google Earth Images. It is essential to know the recent changes in the morphology of the Progo River so that stakeholders can make policies to control human activities that influence the morphology change of the Progo River. 


\section{Literature Review}

\subsection{Factors controlling river morphological changes}

Watershed features that control river morphology include water discharge, topography, riverbank vegetation, and sediment supply (Buffington, 2012). Generally, river morphology changes are influenced by geological, climatic, and anthropogenic conditions (Rinaldi et al., 2016). Geological conditions define tectonic activities, basin settings, and the sequence of rocks or stratigraphic (Suprapto et al., 2017). Current morphological and rock conditions around the river can describe the river's past conditions, such as the rocks that formed it or lithology, the geological structure, and the current erosion and sedimentation processes (Zamroni et al., 2020). Drainage patterns in rivers are influenced by underlying rock lithology and structural control, while the slope of the channel is caused by the geological nature of the basin and the process of sedimentation and erosion. Geological and geomorphological processes from time to time produce the morphology of the current drainage basin (Kulkarni, 2013). Lithology controls the type of rock and soil that develops around the watershed, which controls the movement from upstream to downstream, through the subsurface, and finally flows to the river. Changes in rock conditions on the surface affect subsurface storage (Costigan et al., 2016). The supply of sediment and water controls the channel pattern and river evolution from upstream to downstream. Meanwhile, the sediment supply is affected by the long-term erosion of the landscape around the river (Mueller \& Pitlick, 2013).

Climate is believed to be the dominant factor in the geological time scale that influences streamflow (Dai \& Lu, 2014). Climate is the average environmental conditions such as humidity and rainfall for more than one hundred years. Climate regulates rainfall; then, rainfall controls streamflow (Costigan et al., 2016). Water that flows into a river can come from rain that flows on the surface or groundwater (Zamroni \& Suprapto, 2017). Global climate change is clearly seen in the twentieth and twenty-first centuries. In the case of rivers, global climate change results in floods that modify runoff characteristics and produce meandering channel patterns. In addition, increased denudation, soil erosion, and landslides can increase sediment runoff into rivers (Kiss \& Blanka, 2012). Climate change significantly affects water resources and rivers, especially in tropical countries. The effects of climate change are more dominant in influencing changes in streamflow than land-use changes. A decrease in rainfall, an increase in temperature, and human activities around the river affect sediment reduction into the streamflow and sediment into the sea. Fluvial processes and streamflow changes will affect the river morphology changes due to the disturbance of sediment balance that settles on the riverbed (Shrestha et al., 2020). So it can be concluded that climate controls the evolution of the landscape (Kamarudin et al., 2014).

Human or anthropogenic factors have been recognized as the dominant factor in the amount of sediment runoff into rivers in recent years, even an essential element in shorter periods in the modern era (Dai \& Lu, 2014). Anthropogenic factors that cause river morphology changes include mining pebbles and sand around rivers, hydraulic structure construction, landuse changes, channelization, urbanization (Abate et al., 2015), and deforestation (Coe et al., 2011). Dam construction affects the decline of the amount of sediment supply drastically, especially to the downstream river area (Bentley et al., 2016). Urbanization makes water catchment areas decrease so that high runoff can change river channels. Development projects around the river will increase degradation; then, it will change the river morphology. Changes in land-use can affect the width and depth of the river due to excessive sediment supply. Siltation 
of the river due to excessive sediment supply can cause flooding in settlements around the river (Abate et al., 2015). Deforestation can change biochemical, geomorphological, and hydrological conditions. Deforestation can increase discharge because it increases the area of vacant land, erosion, increases in surface runoff, and changes in infiltration (Coe et al., 2011).

\subsection{Google Earth Images to study morphological changes}

Google Earth is the technology that provides online access to Landsat data archived by USGS (Zurqani et al., 2018). Google Earth Images resulting from images of Google Earth is a geospatial-based platform to overcome several problems such as disaster, environmental protection, climate monitoring, water management, food security, disease, drought, and deforestation (Gorelick et al., 2017). Google Earth provides satellite imagery so that researchers can see changes in the Earth's morphology (Zurqani et al., 2018). It is also useful for understanding land-use change concepts such as population growth and urban area expansion, resulting in loss of open space, agricultural land, and natural vegetation (Bodzin et al., 2014). Tanaka et al. (2016) used Google Earth Images to analyze changes in river morphology. Google Earth Images showed that the riverbank has resulted from the development of the southern end of the sandbanks. In addition, diversion of streamflow can produce modifications to the river estuary sand terrace and sandspit expansion. Google Earth Images even showed decreased open and green space and distribution of ponds around the city due to rapid urbanization and densification (Barau et al., 2015). Google Earth Images are often used to compare the condition of the Earth's surface before and after disasters, such as changes in coastal morphology due to tsunamis and sediment transportation (Udo et al., 2016). Google Earth Images can be used to evaluate changes in land-use, erosion, and sedimentation processes. The sedimentation process can be controlled to anticipate the occurrence of flooding due to an increase in the riverbed (Ghimire \& Higaki, 2015).

\section{Methodology}

The study area is located in Bantul Regency. Daerah Istimewa Yogyakarta Province, Java Island, Indonesia (Figure 1). The size of the Progo River watershed is around 17,432 square kilometers. Many building structures are along the Progo River, such as bridge, revetment, irrigation intake, weir, and groundsill. The Progo River has several tributaries located in Mount Merapi. In addition, the irrigation water of the Kulon Progo Regency and Sleman Regency is taken from the Progo River (Harsanto, 2015; Fitriadin et al., 2017). The study area is focused on the middle-downstream site of the Progo River with a length of around 2.24 kilometers.

The stages in this study are Google Earth Images analysis, field observations, data analysis, discussions, and conclusions. The first stage in this study is Google Earth Images analysis. It is carried out by analyzing the morphological changes of the Progo River from 2012 to 2019. The research is focused on observing changes in the points along the Progo River, including the conditions of land-use changes that occur around the Progo River. The second stage is the field observation. The observation is about human activities that were estimated as the causes of morphological changes in the Progo River. Some human activities found along the Progo River include sand mining and garbage piling along the riverbanks. The next stage is data analysis. Data analysis was conducted by comparing data of Google Earth Images and data of field observations. In addition, information about human activities that have occurred along the Progo River from the literature was also carried out to support data analysis. Based on the data 
analysis, a discussion of the results is carried out to answer this study's purposes. The last step is to make a study conclusion. The flowchart methodology is shown in Figure 2.
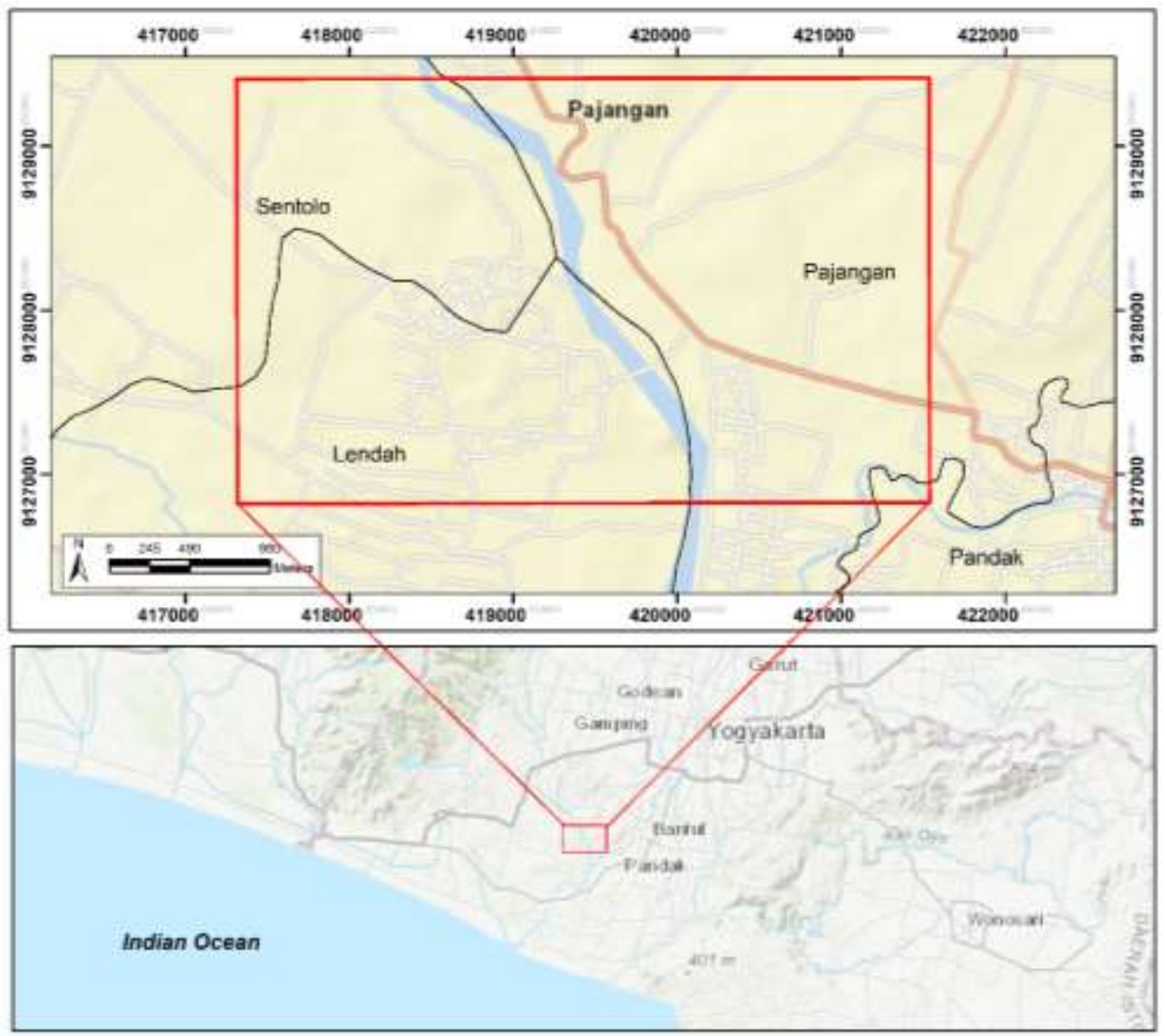

Figure 1. The study area.

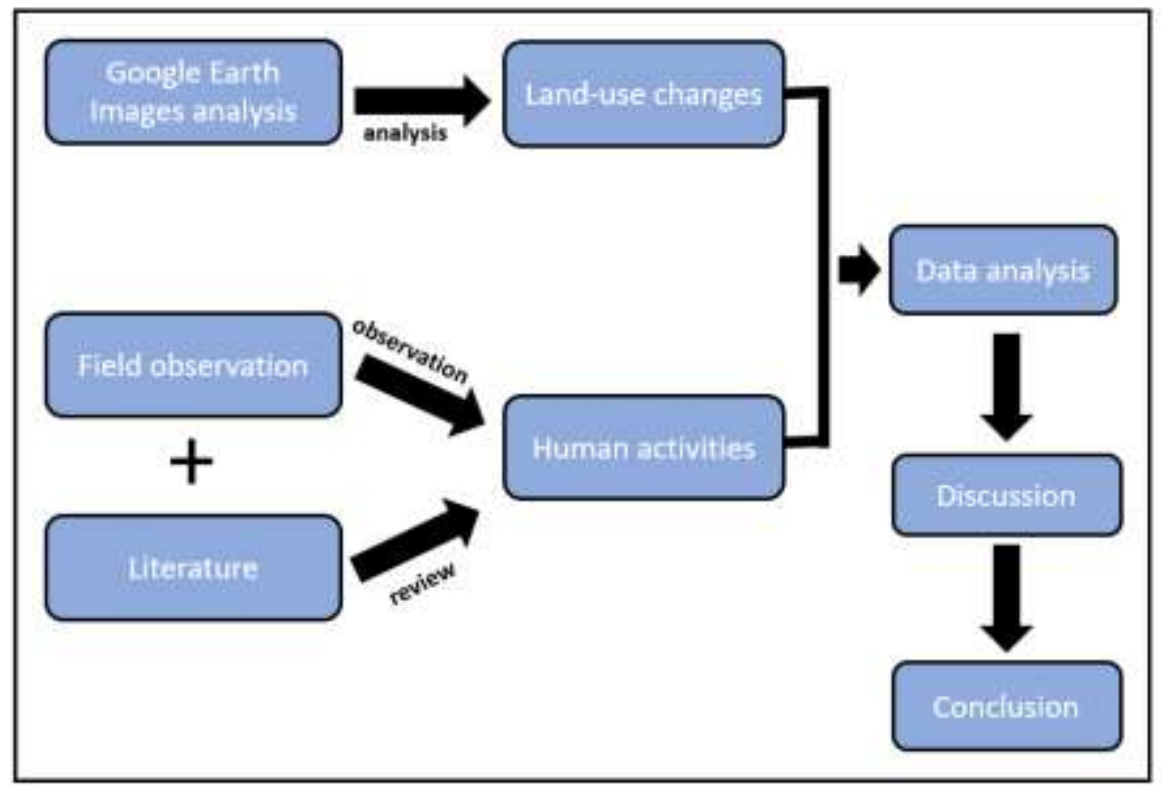

Figure 2. The flowchart methodology. 


\section{Results and Discussions}

\subsection{The effects of land-use changes}

Land-use changes that occur around the Progo River are expected due to the opening of agricultural land, settlement areas, industrial areas, and the construction of the Kamijoro Dam. Figure 3. shows locations on the Google Earth Image that have land-use changes from 2012 to 2019. The observation on each block has been created so that the authors have determined ten locations that have occurred land-use changes (Figure 3). Each location was coded AZ-1 to AZ10. To clarify each location of land-use changes from 2012 to 2019, it enlarges each red box (Figure 4, 5, 6, and 7).

According to Figure 4, the largest land-use change was estimated to begin in 2016 at the start of the Kamijoro Dam construction. Some sediment deposits were reduced in 2016. Based on Google Earth Image of 2017, it shows sediment dredging activities to shift the streamflow to the west so that the initial dam construction can be built on the river's east side. This is supported by Google Earth Image of 2018, which shows that the dam was built in the east by building its primary construction. In 2019, the structure of the Kamijoro Dam had been finished. Figure 5 shows that in the locations of AZ-3 to AZ-7 occurred land-use changes starting in 2015, this is estimated due to the opening of agricultural land (AZ-5 and AZ-7) and settlement areas (AZ-3, AZ-4, and AZ-6) in that location. According to Figure 6. and Figure 7, they show that in the locations of AZ-8 to AZ-10 occurred land-use changes starting in 2015, which is estimated due to the opening of agricultural land in that location.

Land-use changes due to dam construction had an effect on sediment supply downstream of the dam. Figure 4. shows the sediment deposited downstream of the dam in 2017 was starting to decrease. It was estimated that sediment crushing when the dam was being constructed, or sediment supply decreased because it was deposited at the dam. In addition, land-use changes around the Progo River due to the opening of agricultural land and settlement areas had an effect on decreasing the infiltration area, so that the number of trees holding the soil from erosion was reduced, producing more eroded sediment that flowed to the river. These sediments could flow and be deposited in the river, affecting the increase in sediment supply in the river, and it causes river siltation. There are an additional 637 ha of open land and 7,142 ha of plantations around the Progo River. Open land around the Progo River is used for agricultural land, industrial areas, and settlement areas. It causes an increase in erosion, thereby increasing the sediment supply to the Progo River (Rezagama et al., 2019). Still, the data about the relation between the sediment deposited and the opening of agricultural land and settlement areas in this study could not be correlated in detail, so further periodical research is needed.

The authors also attempt to count the quantitative calculation on land-use change in the study area (Figure 8). According to Figure 8, the quantitative calculation on land-use change in the study area from 2012 to 2019 was 42.4 of 1,101.67 hectares the study area total large. 


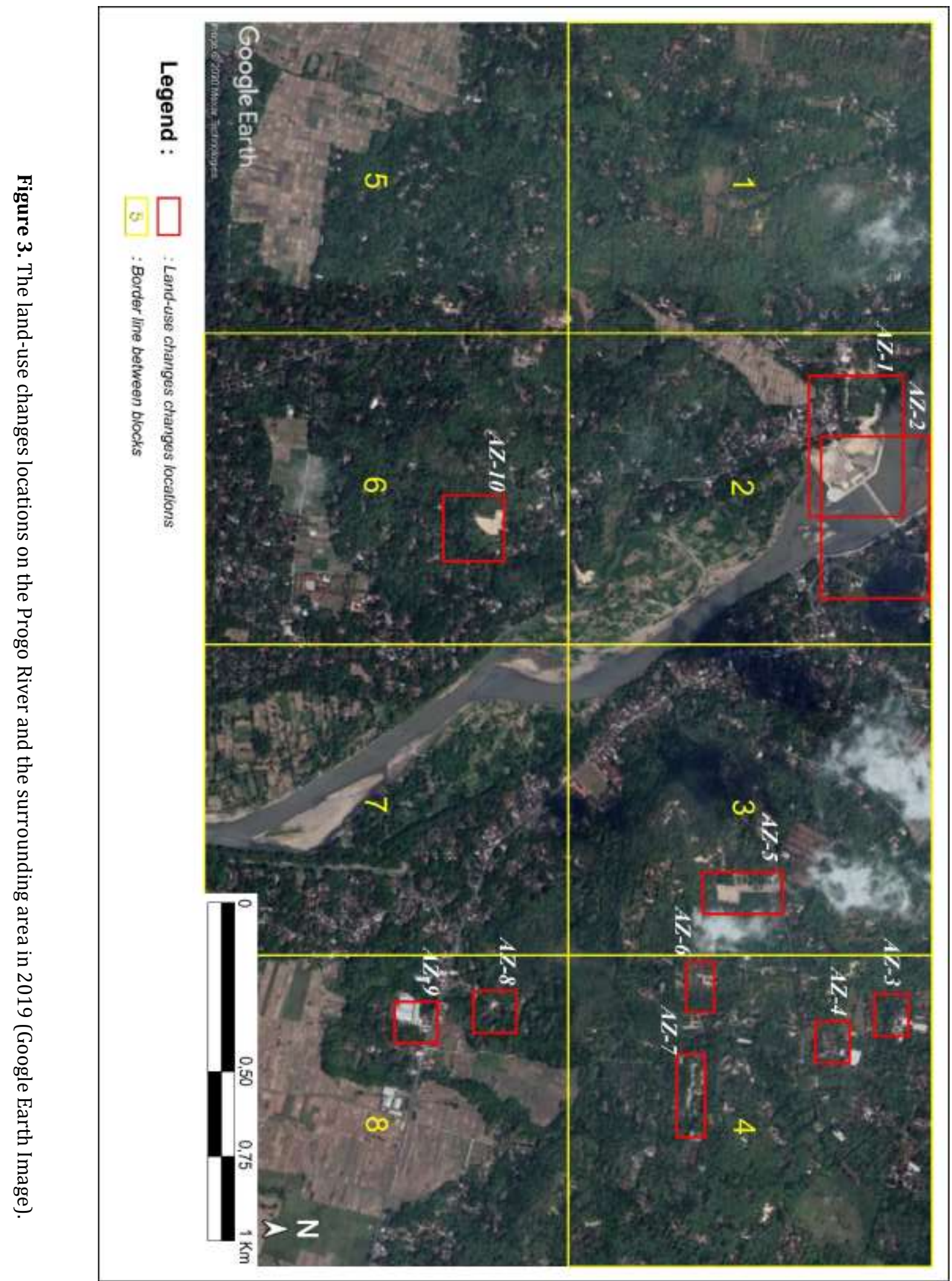




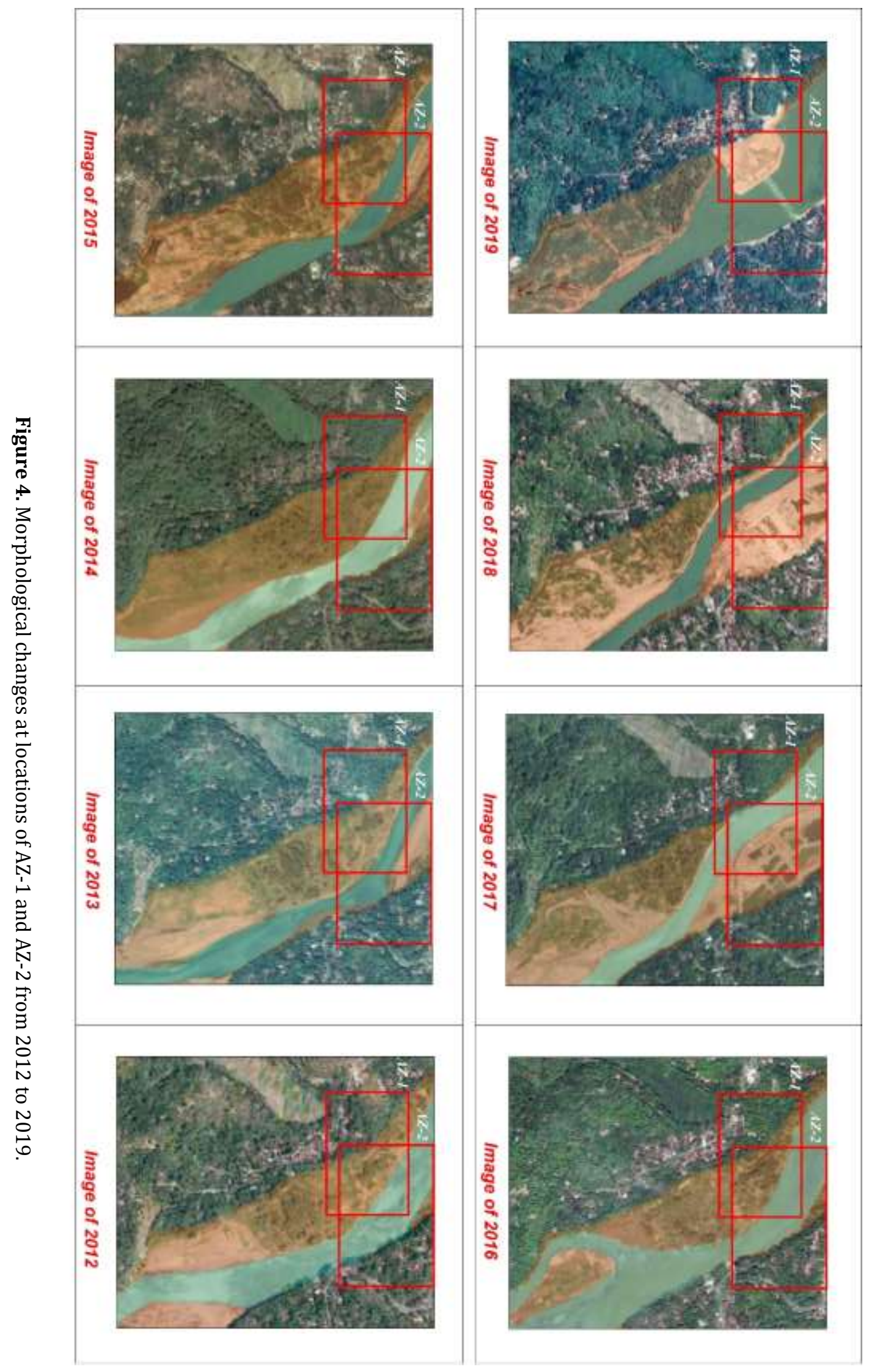



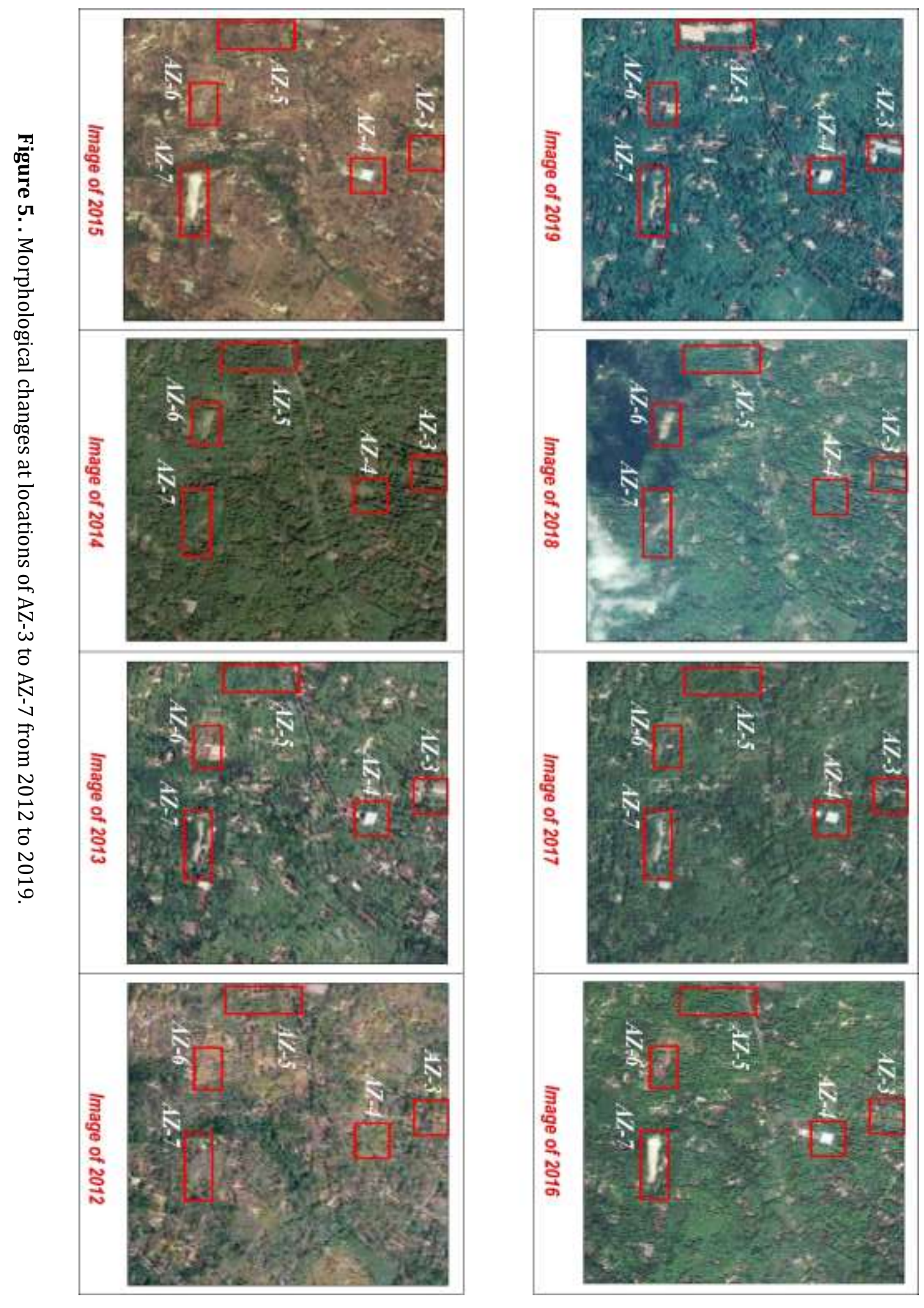

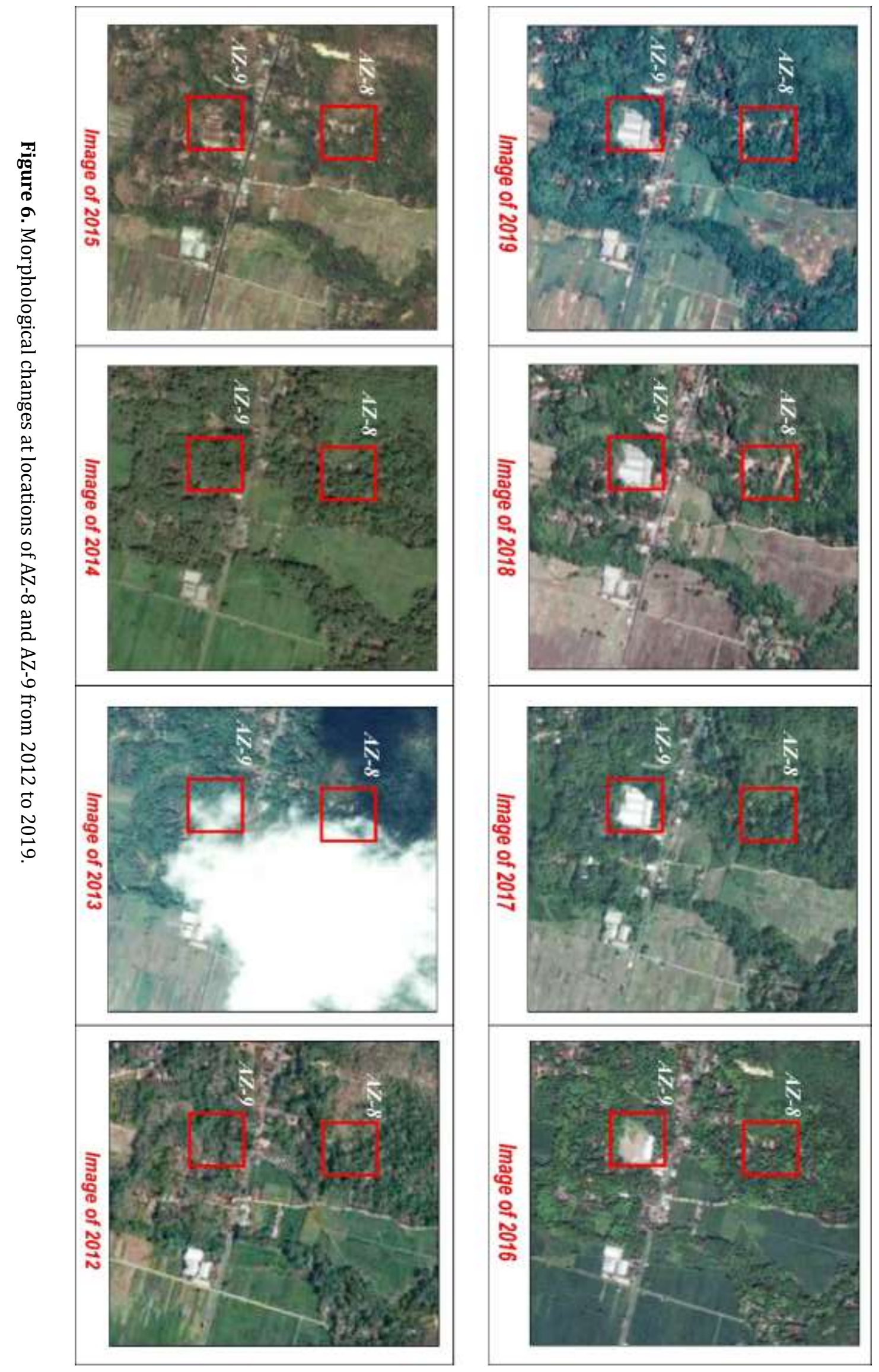

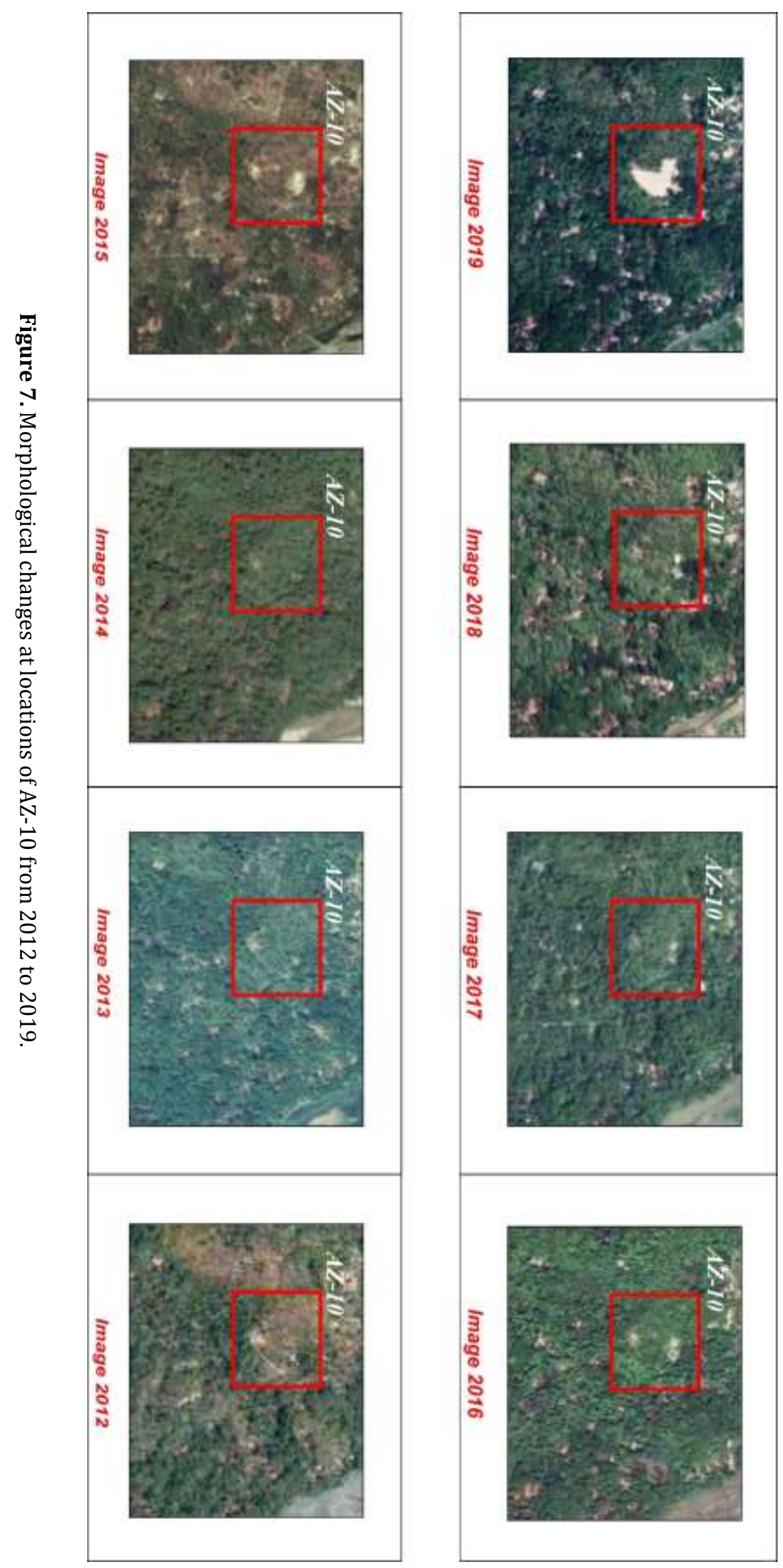


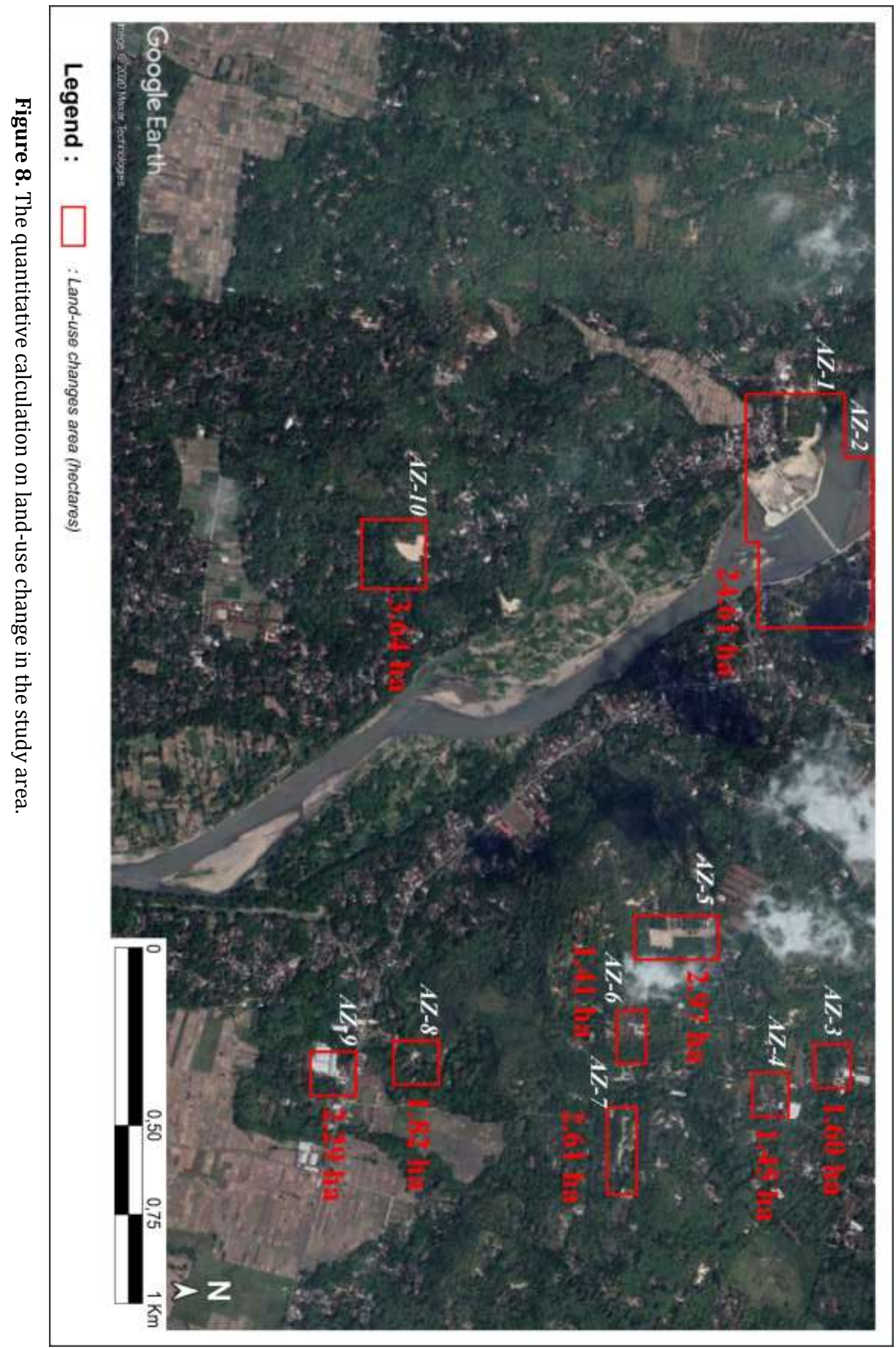




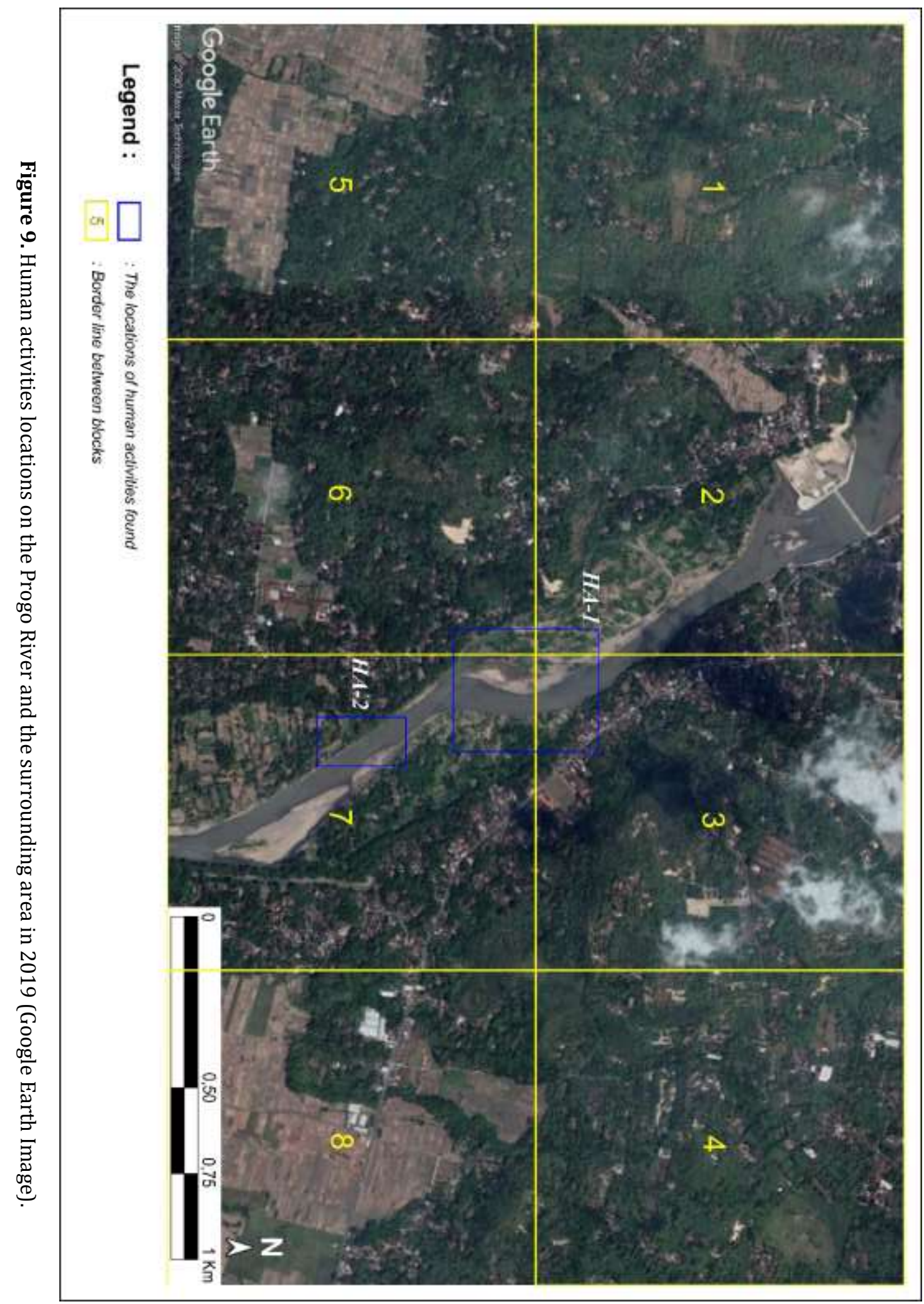




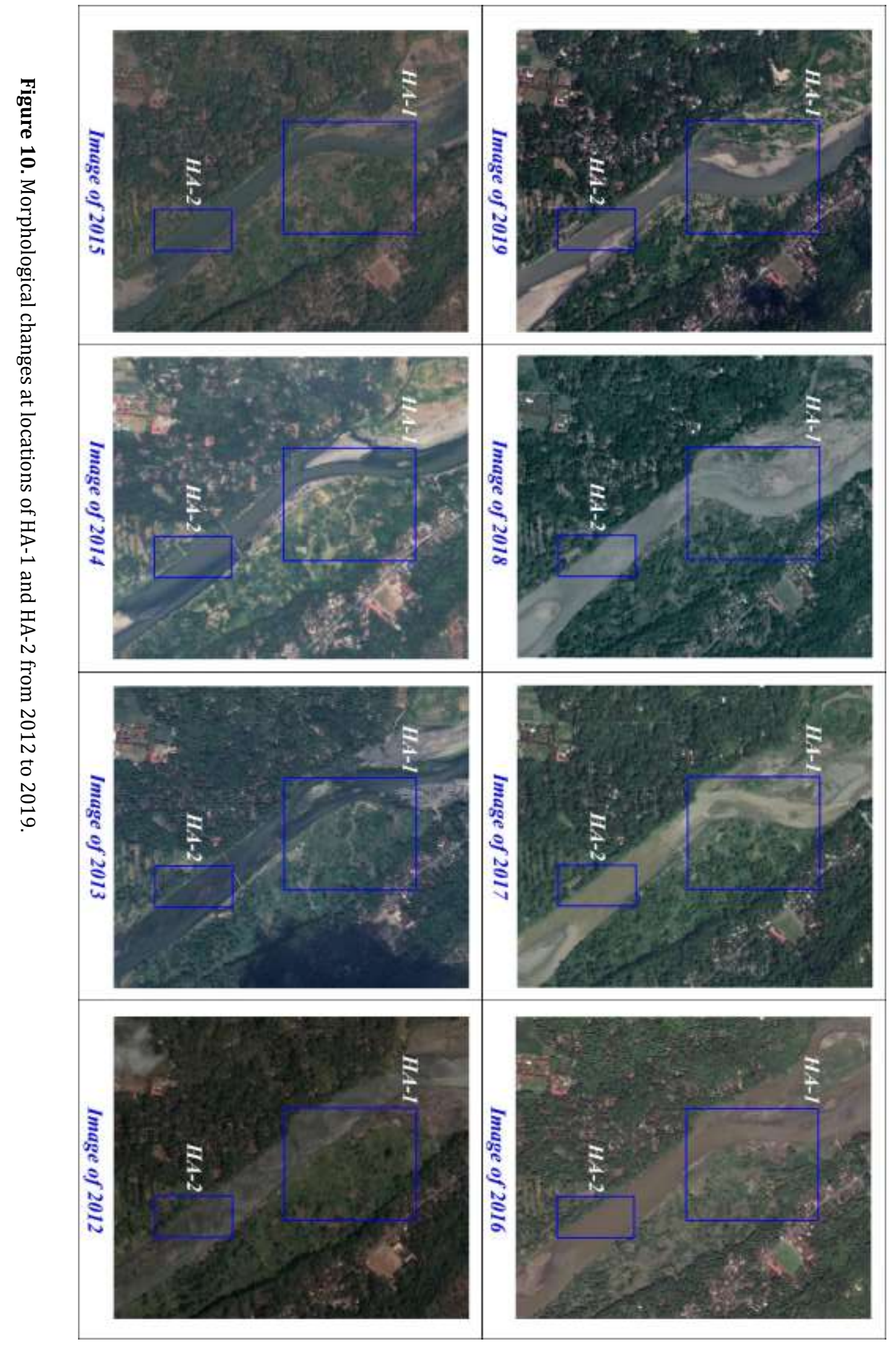




\subsection{The effects of human activities}

Figure 9. shows locations on the Google Earth Image that have human activities from 2012 to 2019. Human activities found in the Progo River and its surrounding area include sand mining activities (Figure 11) and garbage disposal in the river (Figure 12). The observation on each block has been created so that the authors have determined two locations with morphological changes due to human activities (Figure 9). Each location was coded HA-1 and HA-2. To clarify each location of human activities that changed the Progo River morphology from 2012 to 2019, it enlarges each blue box (Figure 10).

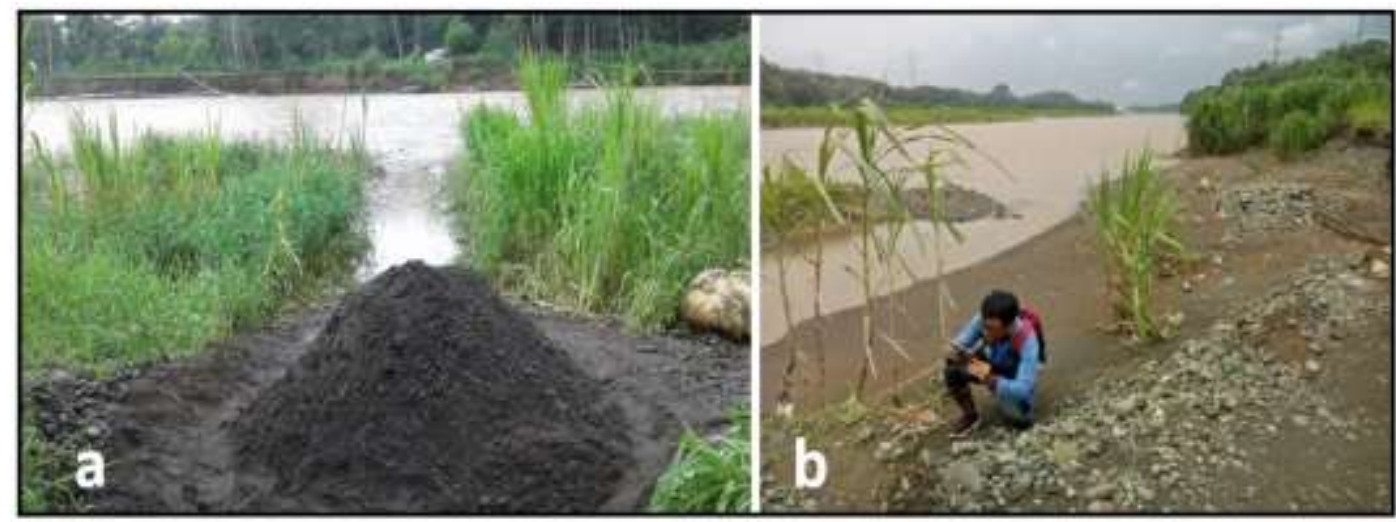

Figure 11. Mining activities along the Progo River. a) Sand mining on the riverbank. b) Location of former sand mining along the Progo River.

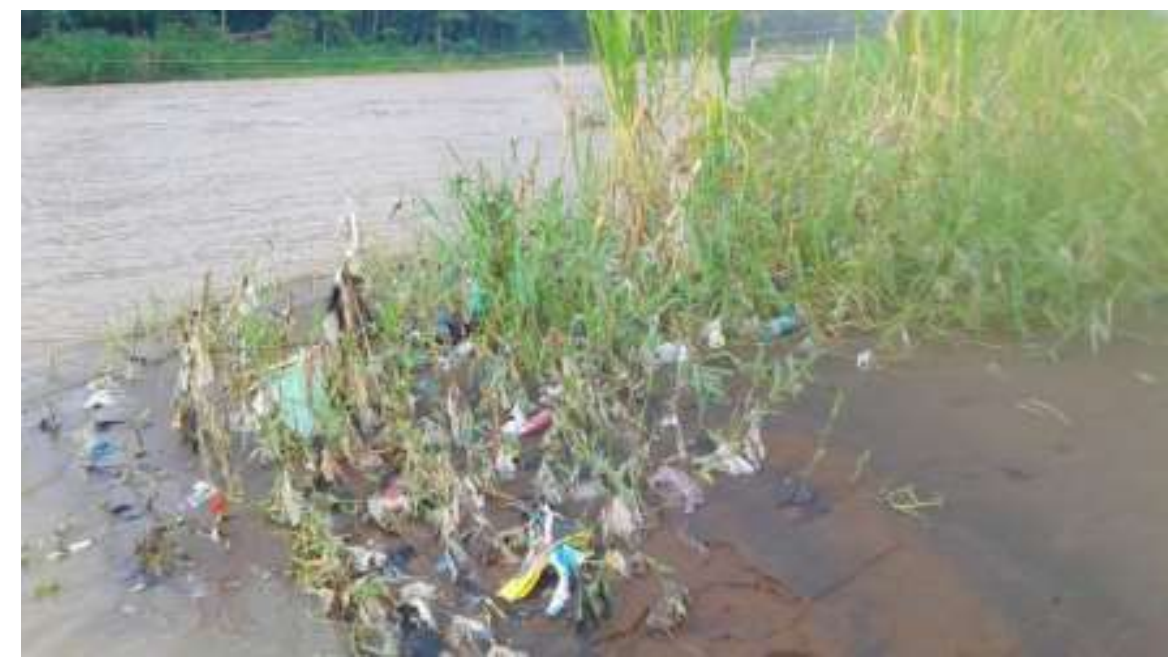

Figure 12. Piles of garbage on the Progo Riverbank.

\subsection{Anthropogenic influences on morphological changes in the Progo River}

Anthropogenic factors in the form of land-use changes and human activities have caused morphological changes in the Progo River from 2012 to 2019. It was significant changes (see the yellow arrow) in the river's direction, which turns more east along 245.82 meters (Figure 13). Changes in the direction of river bends were estimated by several anthropogenic factors such as 
opening agricultural land, settlement areas, industrial areas, dam construction, mining activities, and piles of garbage. However, the relation between each of these anthropogenic factors and the morphological changes of the Progo River could not be correlated in detail, so further periodical research is needed.

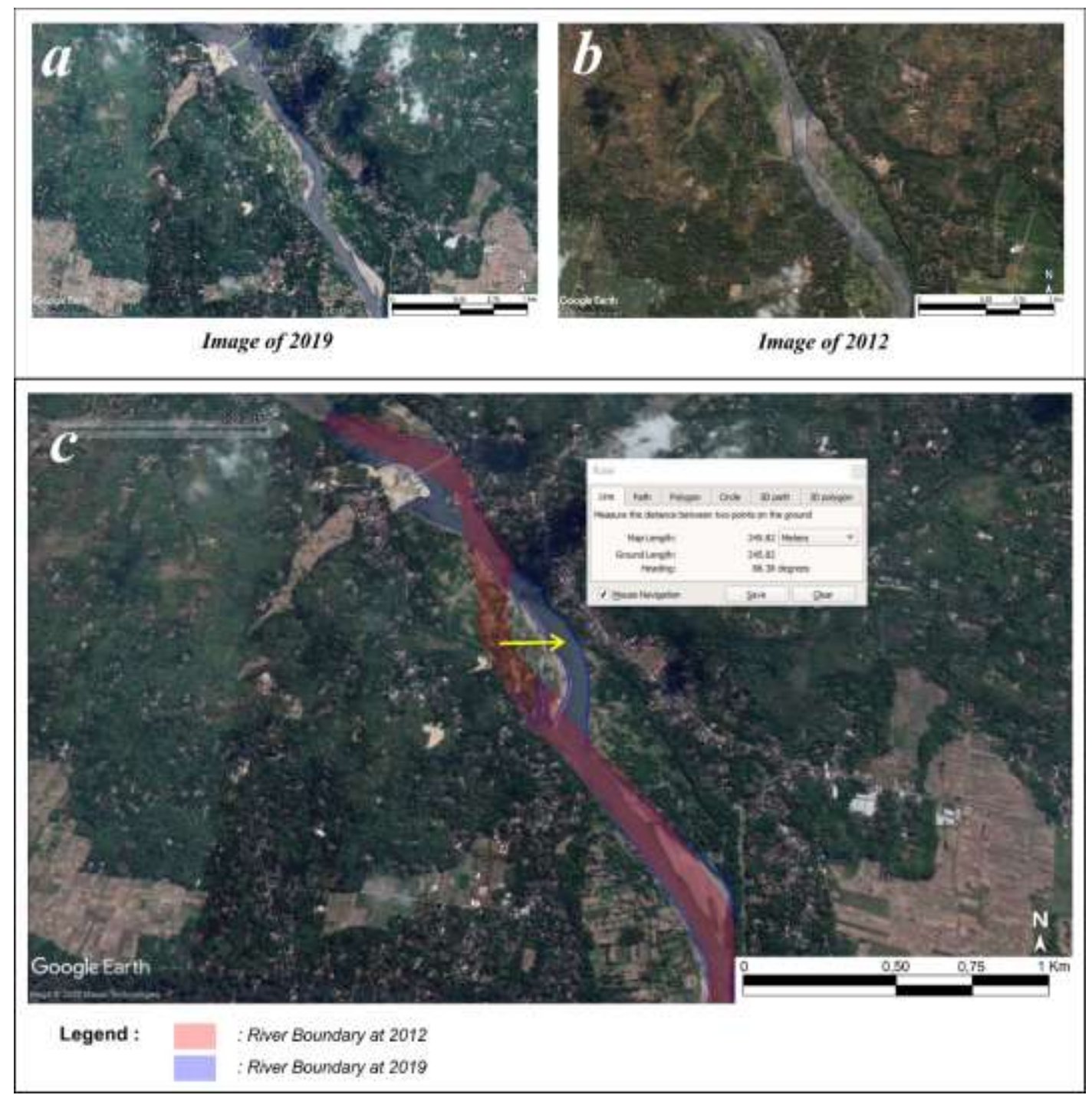

Figure 13. Changes in the direction of river bends which turns more east along 245.82 meters. a) Google Earth Image of 2019. b) Google Earth Image of 2012. c) The direction change of the river.

\section{Conclusion}

Several anthropogenic factors that influence morphological changes in the Progo River are opening agricultural land, settlement areas, industrial areas, dam construction, mining activities, and piles of garbage. Land-use changes due to dam construction affected sediment supply in the downstream of the dam. It was estimated that sediment crushing when the dam was being constructed, or sediment supply decreased because it was deposited at the dam. In addition, land-use changes around the Progo River due to the opening of agricultural land and settlement areas had an effect on decreasing the infiltration area, so that the number of trees holding the 
soil from erosion was reduced, producing more eroded sediment that flowed to the river. Sand mining in the river could cause a deepening of water depths and a decrease in the riverbed's average height. However, the relation between each of these anthropogenic factors and the morphological changes of the Progo River could not be correlated in detail, so further periodical research is needed.

\section{Acknowledgments}

This research was funded by Institut Teknologi Nasional Yogyakarta, Indonesia. We would like to thank some anonymous reviewers whose comments improved the early version of this manuscript's quality.

\section{References}

Abate, M., Nyssen, J., Steenhuis, T.S., Moges, M.M., Tilahun, S.A., Enku, T., \& Adgo, E. (2015). Morphological changes of Gumara River channel over 50 years, upper Blue Nile basin, Ethiopia. Journal of Hydrology, 525, 152-164. http://dx.doi.org/10.1016/i.jhydrol.2015.03.044

Barau, A.S., Maconachie, R., Ludin, A.N.M., \& Abdulhamid, A. (2015). Urban morphology dynamics and environmental change in Kano, Nigeria. Land Use Policy, 42, 307-317. http://dx.doi.org/10.1016/j.landusepol.2014.08.007

Bentley Sr, S.J., Blum, M.D., Maloney, J., Pond, L., \& Paulsell, R. (2016). The Mississippi River source-to-sink system: Perspectives on tectonic, climatic, and anthropogenic influences, Miocene to Anthropocene. Earth-Science Reviews, 153, 139-174. http://dx.doi.org/10.1016/j.earscirev.2015.11.001

Bodzin, A. M., Anastasio, D., \& Kulo, V. (2014). Designing Google Earth activities for learning Earth and environmental science. In Teaching science and investigating environmental issues with geospatial technology (pp. 213-232). Dordrecht.: Springer. doi: https://doi.org/10.1007/978-90-481-3931$\underline{6} 13$

Brunier, G., Anthony, E.J., Goichot, M, Provansal, M., \& Dussouillez, P. (2014). Recent morphological changes in the Mekong and Bassac river channels, Mekong delta: The marked impact of riverbed mining and implications for delta destabilisation. Geomorphology, 224, 177-91. http://dx.doi.org/10.1016/i.geomorph.2014.07.009

Buffington, J.M. (2012). Changes in channel morphology over human time scales [Chapter 32]. In: Church, Michael; Biron, Pascale M.; Roy, Andre G., eds. Gravel-Bed Rivers: Processes, Tools, Environments. Chichester, UK: Wiley. p. 435-463., 435-463. doi: https://doi.org/10.1002/9781119952497.ch32

Coe, M.T., Latrubesse, E.M., Ferreira, M.E., \& Amsler, M.L. (2011). The effects of deforestation and climate variability on the streamflow of the Araguaia River, Brazil. Biogeochemistry, 105(1-3), 119-131. doi: https://doi.org/10.1007/s10533-011-9582-2

Costigan, K.H., Jaeger, K.L., Goss, C.W., Fritz, K.M., \& Goebel, P.C. (2016). Understanding controls on flow permanence in intermittent rivers to aid ecological research: integrating meteorology, geology and land cover. Ecohydrology, 9(7), 1141-1153. doi: https://doi.org/10.1002/eco.1712

Dai, S.B., \& Lu, X.X. (2014). Sediment load change in the Yangtze River (Changjiang): a review. Geomorphology, 215, 60-73. http://dx.doi.org/10.1016/j.geomorph.2013.05.027

Downs, P.W., Dusterhoff, S.R., \& Sears, W.A. (2013). Reach-scale channel sensitivity to multiple human activities and natural events: Lower Santa Clara River, California, USA. Geomorphology, 189, 121-134. http://dx.doi.org/10.1016/i.geomorph.2014.07.009

Du, J.L., Yang, S.L., \& Feng, H. (2016). Recent human impacts on the morphological evolution of the Yangtze River delta foreland: A review and new perspectives. Estuarine, Coastal and Shelf Science, 181, 160-9. http://dx.doi.org/10.1016/j.ecss.2016.08.025 
Fitriadin, A.A., Ikhsan, J.U., \& Harsanto, P. (2017). Morphology analysis in middle-downstream area of Progo River due to the debris flow. In: Green Process, Material, and Energy: A Sustainable Solution for Climate Change. doi: https://doi.org/10.1063/1.4985512

Ghimire, S., \& Higaki, D. (2015). Dynamic river morphology due to land use change and erosion mitigation measures in a degrading catchment in the Siwalik Hills, Nepal. International Journal of River Basin Management, 13(1), 27-39. http://dx.doi.org/10.1080/15715124.2014.963860

Gorelick, N., Hancher, M., Dixon, M., Ilyushchenko, S., Thau, D., \& Moore, R. (2017). Google Earth Engine: Planetary-scale geospatial analysis for everyone. Remote sensing of Environment, 202, 18-27. http://dx.doi.org/10.1016/j.rse.2017.06.031

Harsanto, P. (2015). River morphology modeling at the downstream of Progo River post eruption 2010 of Mount Merapi. In: The 5th Sustainable Future for Human Security (Sustain 2014). pp. 148-157. doi: https://doi.org/10.1016/i.proenv.2015.07.021

Isik, S., Dogan, E., Kalin, L., Sasal, M., \& Agiralioglu, N. (2008). Effects of anthropogenic activities on the Lower Sakarya River. Catena, 75(2), 172-81. doi: https://doi.org/10.1016/i.catena.2008.06.001

Jiang, C., Pan, S., \& Chen, S. (2017). Recent morphological changes of the Yellow River (Huanghe) submerged delta: Causes and environmental implications. Geomorphology, 293, 93-107. doi: https://doi.org/10.1016/i.geomorph.2017.04.036

Kamarudin, M.K.A., Toriman,M. E., Rosli, M.H., Juahir, H., Aziz, N.A.A., Azid, A., ... \& Sulaiman, W.N.A. (2015). Analysis of meander evolution studies on effect from land use and climate change at the upstream reach of the Pahang River, Malaysia. Mitigation and Adaptation Strategies for Global Change, 20(8), 1319-1334. doi: https://doi.org/10.1007/s11027-014-9547-6

Kiss, T., \& Blanka, V. (2012). River channel response to climate-and human-induced hydrological changes: Case study on the meandering Hernád River, Hungary. Geomorphology, 175, 115-25. doi: https://doi.org/10.1016/j.geomorph.2012.07.003

Kulkarni, M.D. (2015). The basic concept to study morphometric analysis of river drainage basin: a review. International Journal of Science and Research, 4(7), 2277-2280.

Lane, S. N., Widdison, P. E., Thomas, R. E., Ashworth, P. J., Best, J. L., Lunt, I. A., ... \& Simpson, C. J. (2010). Quantification of braided river channel change using archival digital image analysis. Earth Surface Processes and Landforms, 35(8), 971-85. doi: https://doi.org/10.1002/esp.2015

Mueller, E. R., \& Pitlick, J. (2013). Sediment supply and channel morphology in mountain river systems: 1. Relative importance of lithology, topography, and climate. Journal of Geophysical Research: Earth Surface, 118(4), 2325-2342. doi: https://doi.org/10.1002/2013JF002843

Pan, L.Z., Ding, P.X., Ge, J.Z., Hu, \& K.L. (2011). Analysis of influence of Deep Waterway Project on morphological change in North Passage of Changjiang Estuary. Journal of Sediment Research, 5: 51-9. doi: https://doi.org/10.1109/RSETE.2011.5964685

Raven, E.K., Lane, S.N., \& Bracken, L.J. (2010). Understanding sediment transfer and morphological change for managing upland gravel-bed rivers. Progress in Physical Geography, 34(1), 23-45. doi: https://doi.org/10.1177/0309133309355631

Rezagama, A., Sarminingsih, A., Zaman, B., \& Handayani, D.S. (2019). Analysis of land use changes effect on erosion and sedimentation potential in Progo watershed. In: Journal of Physics: Conference Series. doi: https://doi.org/10.1088/1742-6596/1217/1/012159

Rinaldi, M., Gurnell, A.M., Del Tánago, M.G., Bussettini, M., \& Hendriks, D. (2016). Classification of river morphology and hydrology to support management and restoration. Aquatic Sciences, 78(1), 17-33. doi: https://doi.org/10.1007/s00027-015-0438-z

Shrestha, S., Imbulana, N., Piman, T., Chonwattana, S., Ninsawat, S., \& Babur, M. (2020). Multimodelling approach to the assessment of climate change impacts on hydrology and river morphology in the $\begin{array}{llll}\text { Chindwin } & \text { River } & \text { Basin, } & \text { Myanmar. Catena, 188, }\end{array}$ https://doi.org/10.1016/i.catena.2020.104464

Suprapto, N., Zamroni, A., \& Yudianto, E.A. (2017). One Decade of the "LUSI" Mud Volcano: Physical, Chemical, and Geological Dimensions. CHEMISTRY, 26(4), 615-629. eid: 2-s2.0-85028600271 
Tanaka, H., Hoang, V.C., \& Viet, N.T. (2016). Investigation of morphological change at the Cua Dai river mouth through satellite image analysis. Coastal Engineering, 2016. doi: https://doi.org/10.9753/icce.v35.sediment.9

Uddin, K., Shrestha, B., \& Alam, M.S. (2011). Assessment of morphological changes and vulnerability of riverbank erosion alongside the river Jamuna using remote sensing. Journal of Earth Science and Engineering, 1(1), 29-34.

Udo, K., Takeda, Y., \& Tanaka, H. (2016). Coastal morphology change before and after 2011 off the Pacific coast of Tohoku earthquake tsunami at Rikuzen-Takata coast. Coastal Engineering Journal, 58(4), 1640016-1. doi: https://doi.org/10.1142/S0578563416400167

Williams, R.D., Rennie, C.D., Brasington, J., Hicks, D.M., \& Vericat, D. (2015). Linking the spatial distribution of bed load transport to morphological change during high-flow events in a shallow braided river. Journal of Geophysical Research: Earth Surface, 120(3), 604-622. doi: https://doi.org/10.1002/ 2014JF003346

Zamroni, A., Sugarbo, O., Prastowo, R., Widiatmoko, F.R., Safii, Y., \& Wijaya, R.A.E. (2020, July). The relationship between Indonesian coal qualities and their geologic histories. In AIP Conference Proceedings (Vol. 2245, No. 1, p. 070005). AIP Publishing LLC. doi: https://doi.org/10.1063/5.0006836

Zamroni, A., \& Suprapto, N. (2017). Exploring of factors influencing the rocks resistivity value: comparative study of resistivity values in some areas. In Prosiding Seminar Nasional Fisika (SNF) (Vol. 1, pp. 49-53).

Zhang, W., Xu, Y., Hoitink, A.J., Sassi, M.G., Zheng J, Chen, X., \& Zhang, C. (2015). Morphological change in the Pearl River Delta, China. Marine Geology, 363, 202-19. doi: https://doi.org/10.1016/j.margeo.2015.02.012

Ziliani, L., \& Surian, N. (2012). Evolutionary trajectory of channel morphology and controlling factors in a large gravel-bed river. Geomorphology, 173, 104-17. doi: https://doi.org/10.1016/i.margeo.2015.02.01

Zurqani, H.A., Post, C.J., Mikhailova, E.A., Schlautman, M.A., \& Sharp, J.L. (2018). Geospatial analysis of land use change in the Savannah River Basin using Google Earth Engine. International journal of applied earth observation and geoinformation, 69, 175-185. https://doi.org/10.1016/i.jag.2017.12.006 